\title{
COPING MECHANISM OF CAREER WOMEN WITH BREAST CANCER
}

\author{
Rosnani \\ Department of Nursing Polytechnic of Health Palembang \\ Jl. Merdeka 10 A Palembang, Telp: (0711) 35106 \\ Email: rosnani@poltekkespalembang.ac.id
}

\begin{abstract}
Introduction: Patients with cancer may experience psychological disorders such as depression, anxiety, anger, helplessness, and unappreciated, so in certain situations require defense mechanisms (coping mechanism) to oppose or resist feelings of anxiety, fear or stress that haunt her. The aim of this study was to know the coping mechanism of career women with breast cancer reviewed by phenomenology in Palembang 2016. Method: Type of this study was a qualitative study with a phenomenological approach. Total samples were 8 participants with inclusion criteria: career women, productive age range, health physic and physiologic. Independent variable was a coping mechanism, and the dependent variable was breast cancer. The instrument used the voice recorder, and interview guides. Data analyze used verbatim transcript with credibility, dependability, and confirmability. Result: The results showed that working women who have breast cancer have a coping strategy that is adjusted to the psychological condition and physical reactions of the therapy in progress. Psychologically, the coping mechanism is in the form of rejecting, drawing closer to Allah SWT, seeking the opinion of other health workers, discussing conditions with spouse and family, seeking alternative treatment and asking for doctor's direction. The coping mechanism of the body's reaction to therapy is done by taking medicine according to the rules and remember Allah SWT. Conclusions: Need the support of the coping mechanism in patients with breast cancer and nursing care approach with the pattern of coping mechanisms with the involvement of the family.
\end{abstract}

Key Words: Coping Mechanism, Breast Cancer, Career Women

\section{INTRODUCTION}

Cancer is the third cause of death globally in $12.5 \%$. This amount exceeds the combined death toll of HIV / AIDS, tuberculosis and malaria. 7 million of deaths caused by cancer (Depkes 2015). At least 1.2 million US residents diagnosed with cancer each year, but the incidence rate is higher in developing countries, including Indonesia (Smeltzer \& Bare 2009).

In Indonesia, the prevalence rate of cancer was quite high. In Asean, Indonesia was on second ranks after Vietnam with 135 thousand cases of cancer each year (WHOdalam Kemenkes 2014). The data from Information Health Ministry Center showed the prevalence of cancer was 100 thousand each year (Kemenkes 2014)

Breast cancer was the most experienced by women after cervical cancer and other cancers. Breast cancer was the height cause of death followed by cervical cancer in the second. An estimated 1.2 Million women diagnosed with breast cancer and more than 700 thousand died, besides every year seem to be more than 250thousand new cases of breast cancer and ranks first among cancers in women with other cancers (Siswono 2007). In
Indonesia, breast cancer was the first ranks cause of death for women followed by cancer of the cervix (cervical) with an incidence of 26 per 10 thousand women (Depkes 2015). Data from (IPKSI 2011) showed that Indonesian women on range 40-45 had cervical cancer each day.

General Hospital of Dr. Mohammad Hoesin Palembang is a Type A hospital and the referral hospital for South Sumatra Province. Based on data from the last visit to patients with cancer was 965 patients covering all types of cancer, especially breast cancer and cervical cancer (RSMH 2015).

Since the last decade of action towards cancer were surgery, radiation, and chemotherapy. The purpose of chemotherapy is healing, control, and palliative used to establish medication used for the aggressiveness of plan therapy (Prawiroharjo 2008). All measures of treatment cause physical changes that indirectly affect psychosocial changes.

Based onSutandyoin (Fachlevy et al. 2013), patients with chemotherapy treatment will experience physical complaints, followed by an emotional setback, social relations disorder, and reduced of communication 
between husband and wife. Besides the action of cancer (chemo, radiation, and surgery) will give effect on the esteem, role and body image, identity, sexuality, and the well-being of the patient. Besides of it, the patient will stress with a diagnosis of cancer that was potentially life-threatening. The changes were very burdensome for the patient, because of that, the treatment of patients with cancers should be done multidiscipline formulated comprehensive in science, and provide a variety of support facilities so that patients can adapt to the conditions and the changes.

The possibility of psychological disorders such as depression, anxiety, anger, helplessness, and unappreciated experienced by $23 \%-60 \%$ of patients with cancers (Lubis \& Hasnida 2009). The situation may cause more severe suffering, weaken the function of organs and can be demoralizing to undergo a series of treatment regimens (Duanne \& Ellen 2013).

Patients with cancer in certain situations require coping mechanisms to oppose or resist feelings of anxiety, fear or stress that haunt her. One of the Conceptual Model affecting nursing is the Roy Adaptation Model. The main idea of Roy Adaptation Model was a system of human adaptation as a bio-psychosocial. Humans respond holistically to the changes in their environment. Roy considers patient has an adaptability in addressing the problem. Nurses in Roy Adaptation Model were required to assess the adaptability of the patient through the regulator or cognator coping mechanisms and recognize the inability of patients who need help.

In Roy Adaptation Model external and internal environment, Human was a stimulus (stimuli adaptation level) that would provide a response through a mechanism of coping (coping mechanism) in the form of coping regulator and cognator which will give effect (effectors) on physiological function and cognition (psychosocial) include self-concept, function role, and dependence, it will generate (output) whether the patient can adapt to the changes that occur (adaptive) or failure to adapt (ineffective).The nurse's role in facilitating the patient in order to adapt is to optimize the social support that exists around the patient. According to (Sheriden \& Radmacher 1992) and (Taylor 1999) divided support into five consists of an instrumental support, informational, emotional, support selfesteem and social support groups.

Based on the above considerations, a qualitative research with descriptive phenomenology method is needed to answer questions about how the response of women career during the experience of cancer; how was the journey of cancer is perceived by women career, how the experiences of women career during therapy and coping mechanisms for women experiencing cancer.

\section{METHOD}

This type of this study was a qualitative research with a phenomenological method. This research was conducted in the house participants domiciled in Palembang, November 2016 Instruments used in this study was a voice recorder, interview guidelines, and field notes.

Participants of this study were women career were diagnosed with cancer in Palembang, with purposive sampling technique, which was in qualitative research was often referred to as judgmental, theoretical or purposeful sampling. The total sample in this study were eight participants. Criteria inclusion for participants in this study includes women career, productive age, patients with good physical and mental health condition.

The independent variables in this study were coping mechanism, and the dependent variables in this study were breast cancer. The data analysis methods from a verbatim transcript based on (Colaizzi 1978) in (Fain 1999).

\section{RESULTS}

\section{Knowledge of breast cancer}

The patient's baseline knowledge of breast cancer chemotherapy was important information for determining the treatment that chosen by the participants. Participants have heard about breast cancer before they undergo treatment. The statements of participants:

"ever, ummm breast cancer was malignant bumps that grow in the breast" (P3).

The knowledge that obtained by participants come from sources that less accurate. Knowledge usually obtained from 
friends, family, neighborhood, and online media. The statements of participants:

"I saw on the internet, and searching on Google..." (P2)

The source knowledge that inaccurate can lead to a negative perception. The results of the interview participants describe that breast cancer is a disease that frightening disease. The statements of participants:

"breasts were throbbing, the feels like was shocked, I felt it like between life and death ..." (P5)

\section{Coping mechanism}

Coping mechanism carried by patients vary widely starting from the first time the cancer was diagnosed in the face of distress they experienced until it had gone through therapy. The coping strategies include refuse, draw closer to Allah, seek the opinion of other health personnel (second opinion), to discuss the situation experienced by couples/families, looking for a wide variety of alternative treatments, ask for referrals doctor who diagnoses related actions to be carried out.

\section{a. Denial}

Denial response occurred in patients in the form of crying, worried thinking about the impact of treatment, embarrassed.

"when doctors explained about my disease, I felt there was wrong...” (P8).

"...sometime when I remembered about my disease, how about the prognosis, sometimes my tears drop, because of the disease..." (P1). "...afraid, because this disease was death...." (P6)

"...no, I embarrassed, but now is not, this disease was not disgraced...” (P2).

\section{b. Closed to Allah SWT}

"Everything has arranged by Allah SWT. I am grateful to Allah to tell in advance to me about my age limit, which may not all people get the information" (P4)

\section{c. Seek the opinion of other health professionals}

“...after the doctor said I had cancer, I did not immediately believe what the doctor said, I see a doctor and then another while wondering also with a midwife that I know" (P8).

\section{d. Discuss the conditions experienced towards couples and families}

"...The first time that I give to know is my husband. I do not have kids ... I sincere after my husband knows about my disease, he wants to get married again. But my husband did not want (P5).

"This disease, never made me desperate, it seems to want to die... then my children said if I death whit who I will stay?" (P7).

\section{e. Looking for an alternative treatment}

"I think if I took chemotherapy, would definitely bother to manage .... family will bother, I should be in the hospital ... while my private employees, if not present, can not be a salary. Although I have insurance, fees for hospital fro more it costs, so ... I wondered alternative" (P1).

\section{f. Request a referral doctor}

"...I immediately wrote to follow what the doctor's advice... as already explained everything, stages, and effects...." (P7).

"doctor advised me to chemo, directly yes I follow it... although I heard it was many side effects of chemotherapy, all depended by my body" (P6).

\section{The side effects of treatment}

The impact of treatment that experienced by the participants, depending on the type of therapy and therapy stages undergone by participants. Physical side effects are generally perceived in advanced breast patients with cancers who undergo chemotherapy are: nausea, vomiting, anorexia, hair loss, fatigue, bone marrow suppression such as anemia. Psychological side effects feeling trauma therapy. The statements of participants:

"when I came home, my body warm..." (P3)

"emmm how to explain it. I felt my body sick, aches, weakness, and difficult to walk....”(P5) "always nausea until my appetite loss...." (P7) "when the sick cam, ouughh I felt that I won't chemo anymore..." (P4)

Coping mechanisms do participants experience a reaction time of therapy done by 
taking medicines according to the rules and the remembrance of Allah:

"to solve it only by that way, drink medicine, and ask to doctor for the same medicine..." (P5)

"I preferred to istighfar, and surrendered to Allah..." (P6).

\section{Family's support}

The entire family of the patient to provide support to patients, tailored to the capabilities of each family, from the moral and material support. From each of the support obtained, a positive impact on participant to continue his life.

"My husband loved me, he always accompanied and fulled my daily needed. My husband told that I couldn't work because of sick, so he will handle to work." (P5).

"my children hug me when I look to take a rest because of sickness, their action that I strength... I must be tough for them" (P7).

\section{Expectations towards family and closest people}

Participants express to have hope for the family to be able to help him continue the task of surrogate mother for her children and her husband to get a good wife.

"sometimes... I want surrogate women to take my position as mother and wife"”(P8)

\section{The hope of participant}

The Hope of participants with this illness that can get through this disease properly. If she should die because of the illness, she wanted to die in the midst of the family.

"I want to heal as normal..." (P5)

"I felt... all effort I have done... if I was gone, I want besides my family" (P2).

\section{DISCUSSION}

Based on the results which have been mentioned in the previous section, the individual experiences when first diagnosed with cancer can lead to changes and actual or potential problems in various aspects. Problems that arise can be either physical or psychological aspect. The problems associated with the physical aspects of the disease may be related complaints such as pain, bleeding, sleeplessness, physical discomfort, and limitations in performing daily activities. While issues related to psychological aspects may be the emergence of negative emotions such as shock, sadness, fear, and anger, and also appeared despair even to suicide. There are also issues related to financial and job changes. It is also in line with previous research which states that at the time of the first diagnosis, the patient will have problems with daily living activities, financial problems along with employment problems, in addition to issues related to physical (Pascoe et al. 2004) and then based on (The Royal Marsde Hospital 2014), person with cancer may experience one or more of the following problems: anxiety, the uncertainty about the future, anger, difficulty of adjustment, the problem of family communication, changes in body image, depression, difficulty making decisions, taboo for a balance the demands of the condition of his illness and treatment for a patient.

Various problems experienced by the patient underlying them to find a way out of the problem. To obtain these solutions, patients need the various aspects of support. In this study identified a variety of patient needs related to their efforts in solving the problem. The needs include family support, social environment support, the support of health professionals, disease-related information, a desire to be able to regulate emotion existing instrumental needs, spiritual needs and responsibilities of the role.

The spiritual aspect was the domain that considered the important and a source of strength that was most often mentioned by the subjects in this study. (Gockel et al. 2007) Explained that the spiritual aspect was an important part of the counseling dimension. Then (Gockel et al. 2007) also explained that patients with cancer looked at the spiritual aspect can improve recovery and improve the condition of 7-stage cancer. Stage include: (1) transparency, (2) changing / shifting spiritual perspective, (3) accept the conditions / going within (4) connects to the spirit (5) clarify (6) setting the intention of healing and (7) follow a guide to a restoration of the condition.

Patients coping towards problems that faced by patients with cancers also mentioned. 
Coping performed by different patients, but it also evident there was some similarities. Schetter, Feinstein and (Taylor et al. 1997) explained that the coping performed patients with cancer would be different depending on the issue or cancerous conditions are experienced. For example, if the patient had no complaints or physical discomfort, then coping adaptive to the type of coping focused on a problem (problem-focused), while for the problems associated with the ambiguity of the future, coping adaptive coping focused on emotions by regulating emotions such as diverting or avoid negative thinking.

There were two factors that become the main determinant in the coping selection of patients with cancer, there was the cancer situation that experienced, and a factor of patient perception towards stress factors encountered. Thus, the more the situation experienced, the more forms of coping performed by patients with cancer (Taylor et al. 1997). Beside of that, there were several factors that can determine the patient's coping taken as socioeconomic level, gender, age, and religious beliefs (Billing \& Moos 1984). Socio-economic levels were associated strongly and consistently against certain coping methods that taken, they tend to choose to cope focused on a problem (problemfocused coping) rather than avoiding everyday problems. In this study, the majority of participants come from socio-economic and low education levels. In this group, they were more likely to accept the condition without digging deeper coping variations that can be taken.

In this study also explained that participants were individuals who live in a family community, which was attached to their roles as wives or partners for a husband and as the mother of the children whose age varies. The role as spouse and mother are also known to impact individual lives of cancer. Spousal support, child, and family can strengthen the patient in dealing with cancerous conditions. Participants many say that the spousal support was very meaningful and give strength to continue to live a life with cancer and its treatment often leaves them tired and painful. (Hagedorn et al. 2008) in their study explained that the spousal could be a key role in helping make decisions about treatment should be performed, providing emotional and instrumental support, in addition to the pair also affect the adjustment of the patient toward cancer. (McClure et al. 2010) Stated that patients with cancer in the early diagnosis, however, will experience depression due to the disease, however, if an individual who has cancer it has a partner who has a positive belief in solving the problem, then that patients with cancers tend to have very low levels of depression. Beside of this, the role of partner to patients with cancers, otherwise patients may also affect the emotional life and also the welfare of his partner. So, the patient and her partner will influence each other in dealing with the impact of cancer on their lives both emotionally and practically everyday activities.

Besides the implications of the spouse, child figure also plays an important role for cancer patients. There were a few participants in the study who had no spouse, they look at the key role in a child and the other support system such as close family or other relationships that are already considered family as a child living in the boarding house boarding house belongs to the patient. Related to the impact on children, cancer conditions can have an impact on the welfare of children. The main factors that cause an impact on children's age and sex of the child (Ohayon \& Braun 2010). Potential impact showed psychological distress, anxiety, loneliness, lack of assistance, and guilty, and children tend not to declare his attention directly but to express it through their behaviors cause difficulties in school and problems with friends (Ohayon \& Braun 2010)

Furthermore, participants express also that they feel have hope again after hearing the experience of other patients who have same cancer and managed to survive and live a daily life well. Group of patients with the same cancer experience can be a great encouragement to continue to be optimistic on medication for that group to give a real picture of the success of cancer treatment.

Hagedorn, et al (2008) explained that support informal and formal social group was the force that most affect patient adaptation to the diagnosis and treatment of cancer. Informal support from other patients who have the same diseases, family members, and health care team may influence adaptation to the 
conditions of his cancer patients, especially in patients with breast cancer.

Informal social support among the same patient have breast cancer influence positively on mobility after mastectomy and may increase perceptions of health and body image, and has been proven to reduce the negative feelings. Then in his research concluded that women who followed a formal group therapy with other cancer patients were found to survive longer than those who do not follow the group therapy session (Van den Borne et al. 1986).

\section{CONCLUSION}

There were seven coping strategies that develop in cancer patients newly diagnosed in this study was among others refused, denial, draw closer to Allah, seek the opinion of other health professionals (second opinion), to discuss the situation experienced by couples/ families, looking for various kinds of treatment alternatives, ask for referrals doctor who diagnoses related actions to be carried out. Copying mechanism while the therapy consists of drink medicine as routine and remember of Allah SWT.

Need the support of the coping mechanism in breast cancer patients and nursing care approach with the pattern of coping mechanisms with the involvement of the family.

\section{REFERENCES}

Billing, A.G. \& Moos, R.H., 1984. Coping Stress and Social Resources Among Adult with Unipolar Depression. Journal of Personality and Social Psychology, 46(4), pp.877-891.

Van den Borne, H., Pruyn, J.F. \& Van Dan de May, K., 1986. Self Help in Cancer Patients: A Review of Studies on the Effect of Contracts Between Fellow Patients. Patient Education \& Counseling, 8, pp.367-385.

Colaizzi, P., 1978. "Psychological Research as a Phenomenologist Views it", in Goulding, Christina, Grounded Theory, Ethnography and phenomenology, Wolverhampton Business School., United Kingdom: Wolverhampton university.

Depkes, R., 2015. Estimasi dan Proyeksi HIV/AIDS di Indonesia. Available at: http://pppl.depkes.go.id/_asset/_downloa d/Estimasi \& proyeksi HIV AIDS di Indonesia th 2011-2016.pdf [Accessed November 21, 2016].

Duanne, S.P. \& Ellen, S.S., 2013. Theories of Personality Tenth Edit. A. Jessica, H. Travis, \& N. Mary, eds., United States of Americal: Jon-David Hague.

Fachlevy, Andi \& Faizal, 2013. Faktor Risiko Kanker Ovarium di RSUP Wahidin Sudirohusodo Makasar. FKM UNHAS, $3(2)$.

Fain, J.., 1999. Nursing Research: Principle and Methods, 6th Editions, Philadelphia: Lippincott, William \& Wilkins.

Gockel, I. et al., 2007. Resection of the Mesopancreas (RMP): A New Surgical Classification of A Known Anatomical Space. World J Surg Oncol, 25(5), p.44.

Hagedorn, M. et al., 2008. Distress in Couples Coping with Cancer: A Meta-Analysis and Critical Review of Role and Gender Effects. Psyco Bull., 134(1), pp.1-30.

Hospital, T.R.M., 2014. Data of Royal Marsden Hospital, United Kingdom.

IPKSI, 2011. Ikatan Peduli Kanker Serviks Indonesia.

Kemenkes, R., 2014. Survey Kesehatan Rumah Tangga (SKRT), Jakarta: Badan Penelitian dan Pengembangan Kesehatan Kementerian Kesehatan.

Lubis, N.L. \& Hasnida, 2009. Terapi Perilaku Kognitif Pada Pasien Kanker, Medan: USU: Press.

McClure, K.. et al., 2010. Social Problem Solving and Depression in Couples Coping with Cancer.

Ohayon, I.H. \& Braun, M., 2010. Being A Parent and Coping with Cancer: Intervention Development. Journal of Palliative and Supportive Care, 9, pp.149-152.

Pascoe, S. et al., 2004. Measuring and Appraising Capacity in Fisheries: Framework, Analytical Tolls and Data Aggregation., USA: FAO Fisheries Circular.

Prawiroharjo, S., 2008. Ilmu Kebidanan, Jakarta: Yayasan Bina Pustaka Sarwono Prawirohardjo.

RSMH, 2015. Data RSUP Mohammad Hoesin Palembang, Palembang.

Sheriden, C.L. \& Radmacher, S.A., 1992. 
Coping Mechanism of Career Women with Breast Cancer (Rosnani)

Health Psycology: Challenging the Biological Model, New York: John Wiley $\&$ Sons, Inc.

Siswono, 2007. Kanker Payudara Bisa

Dideteksi Sendiri. Available at: http://www.gizi.net/cgi-

bin/berita/fullnew.cgi?newsid101055207

4,29807. [Accessed January 1, 2016].
Smeltzer, S.C. \& Bare, B.G., 2009. Buku Ajar Keperawatan Medikal Bedah Brunner \& Suddarth, Jakarta: EGC.

Taylor, S.E., 1999. Health Psychology 4th ed., Boston: Mc. Graw-Hill. International.

Taylor, S.E., Peplau, L.A. \& Sears, D.O., 1997. Social psycology, Prentice Hall: New Jersey. 